\title{
Aplikasi Daya Dukung Tanah Pondasi Dangkal Berbasis MITApp Inventor (Studi Kasus Ruko Jalan Sriwijaya, Wisma Mugasari, dan Gedung Demak)
}

\author{
Arafah Salsabila $^{1 *}$, Patricia Bella Okthadiansari ${ }^{1}$, Daniel Hartono ${ }^{2}$, Budi Setiyadi ${ }^{2}$ \\ *Corresponding email: salsabilarafah66@gmail.com \\ ${ }^{1}$ MahasiswaProgram Studi Teknik Sipil, Fakultas Teknik, UnikaSoegijapranata, Semarang \\ ${ }^{2}$ Dosen Program Studi Teknik Sipil, Fakultas Teknik, UnikaSoegijapranata, Semarang
}

\begin{abstract}
Abstrak
Perencanaan pondasi memerlukan perhitungan daya dukung tanah terhadap kondisi tanah di dalam tanah. Perhitungan daya dukung tanah secara manual akan membutuhkan waktu yang cukup lama dan rumit. Oleh karena itu, dilakukan penelitian untuk meningkatkan suatu aplikasi yang dapat membantu proses perhitungan daya dukung tanah pada pondasi dangkal. Ada dua macam pengujian pada aplikasi, seperti pengujian di lapangan (uji penetrasi kerucut dan uji penetrasi Standar) dan uji laboratorium terhadap sampel tanah. Perhitungan didasarkan pada hasil data Cone Penetration Test (CPT) dengan menggunakan metode Schmertmann. Perhitungan berdasarkan hasil data Standard Penetration Test (SPT) menggunakan metode Meyerhof untuk tanah non-kohesif tetapi Terzaghi dan Peck untuk tanah kohesif. Cara lainnya adalah berdasarkan uji laboratorium terhadap hasil data contoh tanah menggunakan metode Terzaghi. Persentase antara hasil pengujian perhitungan manual dengan program yang menggunakan data CPT terbesar adalah $0,04903 \%$ sedangkan yang menggunakan data SPT adalah 0,064\% dan yang menggunakan data uji laboratorium terbesar adalah $0,556 \%$. Perhitungan daya dukung tanah pada pondasi dangkal menggunakan program yang lebih efektif dan efisien dari segi waktu dibandingkan dengan perhitungan manual.
\end{abstract}

Kata kunci : Pondasi Dangkal, Daya Dukung, Aplikasi.

\begin{abstract}
The foundation planning needs the calculation of soil bearing capacity to the soil conditions in the ground. The calculation of soil bearing capacity manually will need long enough time and is complicated. Therefore, the research is made in order to increase an application which could help the calculation process of soil bearing capacity on shallow foundation. There are two kinds of testing on the application, such as a test in the ground (cone penetration test and Standard penetration test) and the laboratory test of soil sample. The calculation is based on the Cone Penetration Test (CPT) data result using Schmertmann method. The calculation based on Standard Penetration Test (SPT) data results using Meyerhof method for non-cohesive ground but Terzaghi and Peck for cohesive ground. The other method is based on the laboratory test of soil sample data results using the Terzaghi method. The percentage between the manual calculation test result with the program using CPT biggest data is 0,04903\% whereas using the SPT data is 0,064\% and which is using the biggest laboratory test data is $0,556 \%$. The calculation of soil bearing capacity on shallow foundation using the more effective and efficient program in terms of time compared with the manual calculation.
\end{abstract}

Keywords: Shallow Foundation, Bearing Capacity, Application. 


\section{PENDAhuluan}

\subsection{Latar Belakang}

Pondasi atau struktur bawah merupakan salah satu bagian paling penting untuk mendukung keamanan dan kestabilan bangunan. Perencanaan pondasi memerlukan perhitungan analisis daya dukung tanah terhadap kondisi di lapangan dan di laboratorium. Perhitungan daya dukung tanah pondasi dangkal menggunakan manual akan membutuhkan pengetahuan yang cukup rumit terutama bagi orang yang belum berpengalaman. Seiring dengan perkembangan zaman para insinyur atau engineer dituntut untuk melakukan pekerjaan yang lebih cepat dan tepat.

\subsection{Rumusan Masalah}

ini yaitu:

Rumusan masalah pada penelitian

1. Bagaimana melakukan perhitungan daya dukung tanah pondasi dangkal yang efektif dan efisien?

2. Berapa persentase selisih antara perhitungan manual dengan perhitungan menggunakan aplikasi?

\subsection{Tujuan Penulisan Tugas Akhir}

Tujuan penelitian ini yaitu:

1. Membuat aplikasi perhitungan daya dukung tanah pondasi dangkal yang dapat diakses oleh pengguna smartphone android.

2. Mengetahui besar persentase selisih antara perhitungan manual dengan perhitungan aplikasi.

\subsection{Manfaat Penelitian} yaitu:

Manfaat dari pembuatan aplikasi

1. Menghemat waktu dan meminimalisir kesalahan perhitungan dalam menentukan perencanaan daya dukung tanah pondasi dangkal.
2. Mempermudah seseorang melalui smartphone berbasis android untuk dapat mengetahui daya dukung tanah pondasi dangkal.

\subsection{Batasan Penelitian}

Batasan penelitian untuk membatasi ruang lingkup pembahasan yaitu:

1. Hasil aplikasi program hanya sampai menentukan daya dukung ijin ( $\left.\mathrm{q}_{\mathrm{a}}\right)$ tanah pondasi dangkal.

2. Penyimpanan hasil data yang disimpan tidak dapat dibagikan ke pengguna lain.

3. Data hasil perhitungan yang tersimpan tidak dapat disunting atau edit.

4. Tabel data penyelidikan tanah hasil CPT yang muncul dalam aplikasi hanya dari kedalaman pondasi sampai lebar pondasi di bawah dasar pondasi, sedangkan untuk SPT dari permukaan tanah sampai kedalaman lebar pondasi di bawah dasar pondasi.

5. Perhitungan berdasarkan data hasil CPT dan SPT pada program tidak dipengaruhi muka air tanah.

6. Perhitungan berdasarkan data hasil uji laboratorium sampel tanah pada program hanya dapat menghitung untuk 1 lapisan tanah.

7. Output program antara lain :

a. Data hasil CPT menggunakan metode Schmertmenn dengan jenis pondasi menerus dan pondasi setempat berbentuk bujur sangkar.

b. Data hasil SPT menggunakan metode Meyerhof dengan jenis pondasi menerus atau pondasi setempat, sedangkan jika menggunakan tabel dari Terzaghi dan Peck dengan jenis pondasi memanjang dan pondasi setempat bujur sangkar.

c. Data hasil uji laboratorium sampel tanah dengan jenis pondasi menerus, pondasi setempat berbentuk empat 
persegi panjang, bujur sangkar, dan lingkaran.

\section{TINJAUAN PUSTAKA}

\subsection{Uraian Umum}

Pada zaman modern ini perhitungan daya dukung dapat dilakukan melalui sebuah aplikasi. Contoh beberapa software yang dapat digunakan untuk membuat aplikasi perhitungan ini adalah Microsoft Visual Basic 6, Android Studio, Eclipse, Adobe Flash, dan lain-lain. Pada penelitian ini software yang akan kami gunakan yaitu MIT APP Inventor yang hasil program nantinya dapat diakses oleh siapa saja melalui smartphone.

\subsection{Jenis-Jenis Tanah}

Beberapa istilah tanah berdasarkan ukuran partikelnya antara lain:

1. Kerikil (gravels) merupakan batuan kecil atau kepingan batuan yang memiliki ukuran butiran antara $2-75$ $\mathrm{mm}$.

2. Pasir (sand) merupakan partikel yang berukuran $0,075-2 \mathrm{~mm}$.

3. Lanau (silts) merupakan partikel tanah yang berukuran sangat kecil antara $0,002-0,06 \mathrm{~mm}$.

4. Lempung (clays) merupakan partikel tanah yang sangat halus yang mempunyai ukuran $<0,002 \mathrm{~mm}$.

\subsection{Daya Dukung Tanah Pondasi Dangkal}

Menurut Peraturan Pembebanan Indonesia Untuk Gedung tahun 1983, standar daya dukung tanah dibagi menjadi:

1. Tanah keras, daya dukung lebih dari 5 $\mathrm{kg} / \mathrm{cm}^{2}$.

2. Tanah sedang, daya dukung $2-5 \mathrm{~kg} /$ $\mathrm{cm}^{2}$

3. Tanah lunak, daya dukung $0,5-2$ $\mathrm{kg} / \mathrm{cm}^{2}$.
4. Tanah sangat lunak, daya dukung $0-$ $0,5 \mathrm{~kg} / \mathrm{cm}^{2}$.

\subsubsection{Jenis Pondasi Dangkal}

Beberapa jenis pondasi dangkal antara lain:

1. Pondasi Menerus (Continuous Foundation)

2. Pondasi Telapak atau Setempat

3. Pondasi Rakit (Mat Foundation)

4. Pondasi Gabungan

5. Pondasi Struktur Cangkang (Shell Foundation).

\subsubsection{Tipe Keruntuhan Pondasi Dangkal}

Menurut Hardiyatmo (1996)

pembebanan dilakukan secara bertahap dan keruntuhan pondasi dibagi menjadi tiga fase, yaitu fase I, fase II, dan fase III. Berikut gambar fase-fase keruntuhan tanah.

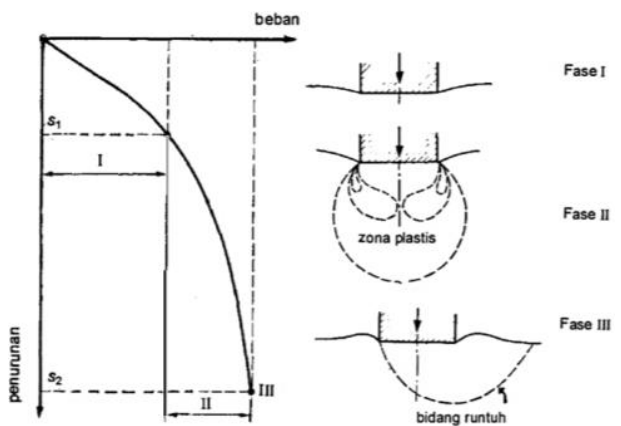

Gambar 1. Fase Keruntuhan Pondasi (Sumber: Teknik Pondasi I, Hardiyatmo 1996).

Mekanisme keruntuhan pondasi dibagi menjadi 3 macam (Vesic, 1963 dalam Hardiyatmo, 1996) yaitu:

1. Keruntuhan Geser Umum (General Shear Failure)

2. Keruntuhan Geser Lokal (Local Shear Failure) 
3. Keruntuhan Penetrasi (Penetration Failure)

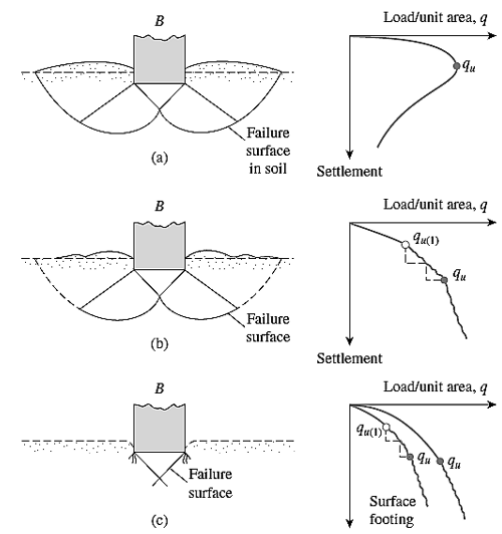

Gambar 2. Macam Mekanisme Keruntuhan Pondasi (Sumber: Principles of Foundation

Engineer 7th Edition, Braja Das 2011).

\subsubsection{Daya Dukung Berdasarkan Hasil Cone Penetration Test (CPT)}

Penentuan klasifikasi tanah dengan menggunakan grafik hubungan antara $\mathrm{q}_{\mathrm{c}}$ dan $F_{r}$ dengan metode Schmertmann seperti pada gambar dibawah ini.

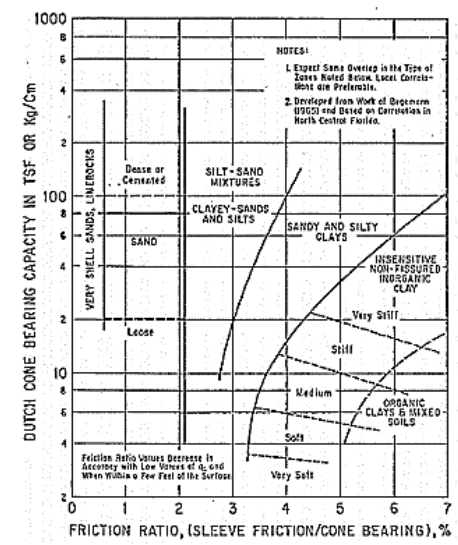

Gambar 3. Grafik Klasifikasi Tanah dari Hubungan Nilai $q_{c}$ dan $F_{r}$ (Sumber: Schmertmann 1978).

Menurut Schmertmann (1978), untuk tanah non kohesif seperti tanah pasir dan kerikil daya dukung tanah dihitung menggunakan rumus sebagai berikut :
1. Pondasi lajur atau menerus, $\mathrm{q}_{\mathrm{u}}=28-0,0052\left(300-\mathrm{q}_{\mathrm{c}}\right)^{1,5} \quad\left(\mathrm{~kg} / \mathrm{cm}^{2}\right)$

2. Pondasi telapak bujur sangkar, $\mathrm{q}_{\mathrm{u}}=48-0,009\left(300-\mathrm{q}_{\mathrm{c}}\right)^{1,5} \quad\left(\mathrm{~kg} / \mathrm{cm}^{2}\right)$

Untuk tanah kohesif seperti tanah lempung dan lanau, yaitu sebagai berikut :

1. Pondasi lajur atau menerus, $\mathrm{q}_{\mathrm{u}}=2+0,28 \mathrm{q}_{\mathrm{c}} \quad\left(\mathrm{kg} / \mathrm{cm}^{2}\right)$

2. Pondasi telapak bujur sangkar, $\mathrm{q}_{\mathrm{u}}=5+0,34 \mathrm{q}_{\mathrm{c}}$

$\left(\mathrm{kg} / \mathrm{cm}^{2}\right)$

\subsubsection{Daya Dukung Berdasarkan Hasil Standard Penetration Test (SPT)}

Berikut rumus yang digunakan Meyerhof dalam menghitung daya dukung ijin yang dikaitkan dengan nilai SPT untuk pondasi setempat dan menerus :

1. Dengan lebar $\mathrm{B} \leq 1,2 \mathrm{~m}$,

$\mathrm{q}_{\mathrm{a}}=1,22 \mathrm{~N}$

$\left(\mathrm{t} / \mathrm{m}^{2}\right)$

2. Dengan lebar B $>1,2 \mathrm{~m}$,

$$
\mathrm{q}_{\mathrm{a}}=0,54 \mathrm{~N}\left(\frac{\mathrm{B}+0,3}{\mathrm{~B}}\right)^{2} \quad\left(\mathrm{t} / \mathrm{m}^{2}\right)
$$

Klasifikasi tanah lempung menggunakan tabel dari Terzaghi dan Peck (1948) yaitu:

Tabel 1. Kapasitas Daya Dukung Tanah Lempung

\begin{tabular}{|c|c|c|c|}
\hline \multirow{2}{*}{ Konsistensi } & \multirow{2}{*}{ NSPT } & \multicolumn{2}{|c|}{$\begin{array}{c}\text { Kapasitas } \\
\text { Dukung Ijin } \\
\left(\mathbf{k N} / \mathbf{m}^{2}\right)\end{array}$} \\
\hline & & $\begin{array}{c}\text { Bujur } \\
\text { Sangkar }\end{array}$ & $\begin{array}{c}\text { Meman } \\
\text {-jang }\end{array}$ \\
\hline $\begin{array}{l}\text { Sangat } \\
\text { lunak }\end{array}$ & $\begin{array}{c}0- \\
2\end{array}$ & $0-30$ & $0-22$ \\
\hline Lunak & $\begin{array}{c}2- \\
4 \\
\end{array}$ & $30-60$ & $22-45$ \\
\hline
\end{tabular}




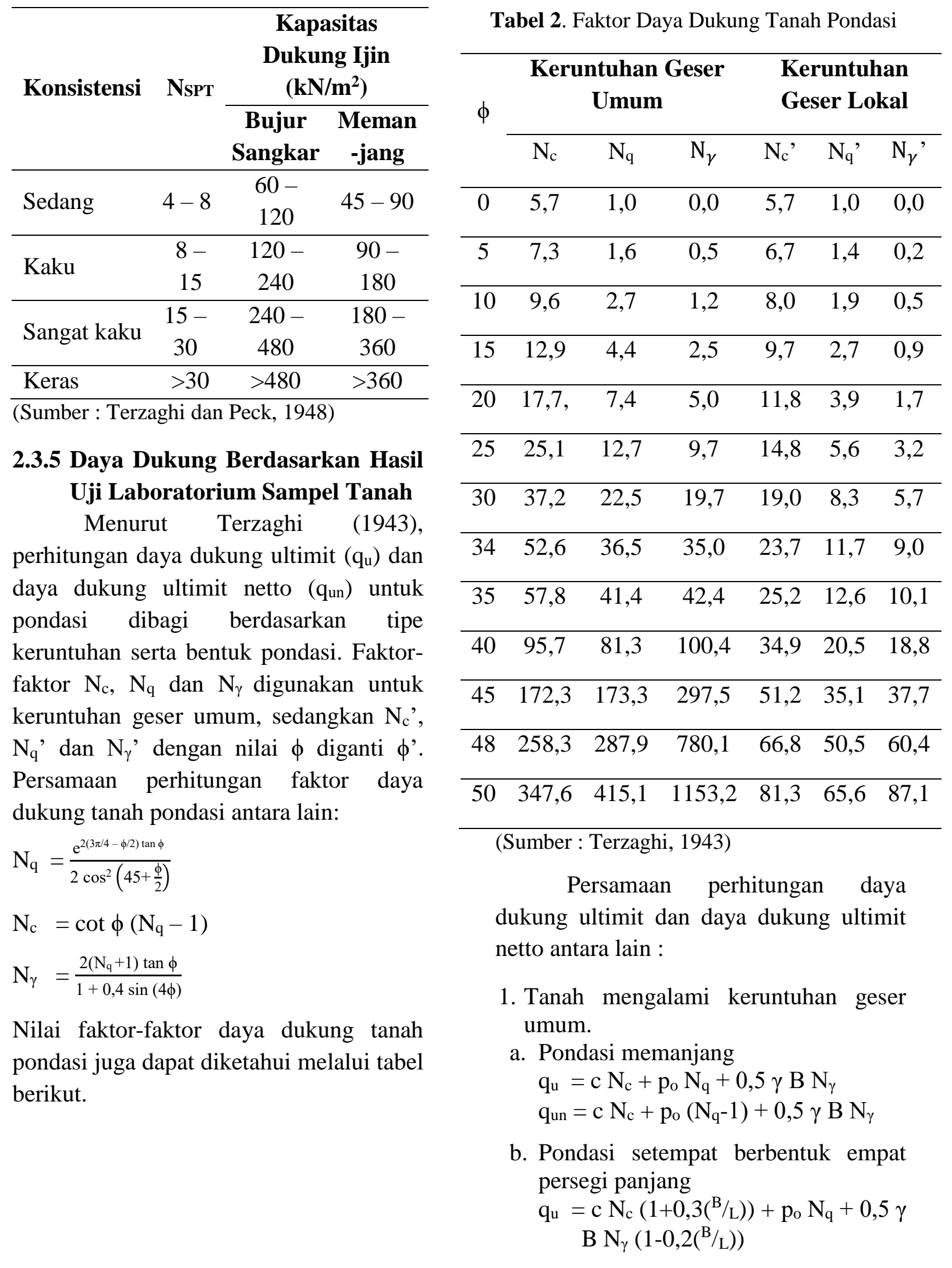




$$
\begin{gathered}
\mathrm{q}_{\text {un }}=\mathrm{c} \mathrm{N}_{\mathrm{c}}\left(1+0,3\left({ }^{\mathrm{B}} / \mathrm{L}\right)\right)+\mathrm{p}_{\mathrm{o}}\left(\mathrm{N}_{\mathrm{q}}-1\right)+ \\
0,5 \gamma \mathrm{B} \mathrm{N}_{\gamma}\left(1-0,2\left({ }^{\mathrm{B}} / \mathrm{L}\right)\right)
\end{gathered}
$$

c. Pondasi setempat berbentuk bujur sangkar

$$
\begin{aligned}
& q_{u}=1,3 c N_{c}+p_{o} N_{q}+0,4 \gamma B N_{\gamma} \\
& q_{u n}=1,3 c N_{c}+p_{o}\left(N_{q}-1\right)+0,4 \gamma B N_{\gamma}
\end{aligned}
$$

d. Pondasi setempat berbentuk lingkaran $\mathrm{q}_{\mathrm{u}}=1,3 \mathrm{c} \mathrm{N}_{\mathrm{c}}+\mathrm{p}_{\mathrm{o}} \mathrm{N}_{\mathrm{q}}+0,3 \gamma \mathrm{B} \mathrm{N} \mathrm{N}_{\gamma}$ $\mathrm{q}_{\mathrm{un}}=1,3 \mathrm{c} \mathrm{N} \mathrm{N}_{\mathrm{c}}+\mathrm{p}_{\mathrm{o}}\left(\mathrm{N}_{\mathrm{q}}-1\right)+0,3 \gamma \mathrm{B} \mathrm{N}_{\gamma}$

2. Tanah mengalami keruntuhan geser lokal.

Nilai c diganti c', dimana c' $=2 / 3$ c

a. Pondasi memanjang

$$
\begin{aligned}
& \mathrm{q}_{\mathrm{u}}=\mathrm{c}^{\prime} \mathrm{N}_{\mathrm{c}}{ }^{\prime}+\mathrm{p}_{\mathrm{o}} \mathrm{N}_{\mathrm{q}}{ }^{\prime}+0,5 \gamma \mathrm{B} \mathrm{N}_{\gamma}{ }^{\prime} \\
& \mathrm{q}_{\mathrm{un}}=\mathrm{c}^{\prime} \mathrm{N}_{\mathrm{c}}{ }^{\prime}+\mathrm{p}_{\mathrm{o}}\left(\mathrm{N}_{\mathrm{q}}-1\right)+0,5 \gamma \mathrm{B} \mathrm{N}_{\gamma},
\end{aligned}
$$

b. Pondasi setempat berbentuk empat persegi panjang

$\mathrm{q}_{\mathrm{u}}=\mathrm{c}^{\prime} \mathrm{N}_{\mathrm{c}}{ }^{\prime}\left(1+0,3\left({ }^{\mathrm{B}} / \mathrm{L}\right)\right)+\mathrm{p}_{\mathrm{o}} \mathrm{N}_{\mathrm{q}}{ }^{\prime}+0,5$

$\gamma \mathrm{B} \mathrm{N}_{\gamma}{ }^{\prime}\left(1-0,2\left({ }^{\mathrm{B}} / \mathrm{L}\right)\right)$

$\mathrm{q}_{\mathrm{un}}=\mathrm{c}^{\prime} \mathrm{N}_{\mathrm{c}}{ }^{\prime}\left(1+0,3\left({ }^{\mathrm{B}} / \mathrm{L}\right)\right)+\mathrm{p}_{\mathrm{o}}\left(\mathrm{N}_{\mathrm{q}}{ }^{\prime}-1\right)$

$+0,5 \gamma \mathrm{B} \mathrm{N}_{\gamma}{ }^{\prime}\left(1-0,2\left({ }^{\mathrm{B}} / \mathrm{L}\right)\right)$

c. Pondasi setempat berbentuk bujur sangkar

$$
\begin{aligned}
& \mathrm{q}_{\mathrm{u}}=1,3 \mathrm{c}^{\prime} \mathrm{N}_{\mathrm{c}}{ }^{\prime}+\mathrm{p}_{\mathrm{o}} \mathrm{N}_{\mathrm{q}}{ }^{\prime}+0,4 \gamma \mathrm{B} \mathrm{\textrm {N } _ { \gamma }}{ }^{\prime} \\
& \mathrm{qun}_{\mathrm{un}}=1,3 \mathrm{c}^{\prime} \mathrm{N}_{\mathrm{c}}{ }^{\prime}+\mathrm{p}_{\mathrm{o}}\left(\mathrm{N}_{\mathrm{q}}{ }^{\prime}-1\right)+0,4 \gamma \mathrm{B} \\
& \mathrm{N}_{\gamma}{ }^{\prime}
\end{aligned}
$$

d. Pondasi setempat berbentuk lingkaran $\mathrm{q}_{\mathrm{u}}=1,3 \mathrm{c}^{\prime} \mathrm{N}_{\mathrm{c}}{ }^{\prime}+\mathrm{p}_{\mathrm{o}} \mathrm{N}_{\mathrm{q}}{ }^{\prime}+0,3 \gamma \mathrm{B} \mathrm{N} \mathrm{N}_{\gamma}{ }^{\prime}$ $\mathrm{q}_{\mathrm{un}}=1,3 \mathrm{c}^{\prime} \mathrm{N}_{\mathrm{c}}{ }^{\prime}+\mathrm{p}_{\mathrm{o}}\left(\mathrm{N}_{\mathrm{q}}{ }^{\prime}-1\right)+0,3 \gamma \mathrm{B}$ $\mathrm{N}_{\gamma}$ '

Nilai $p_{o}$ merupakan nilai tekanan overburden, dimana $\mathrm{p}_{\mathrm{o}}=\mathrm{D}_{\mathrm{f}} \gamma$. Jika terdapat muka air tanah, maka akan dibagi menjadi 3 kondisi seperti yang ditunjukkan di bawah ini.
1. Kondisi 1: $\mathrm{p}_{\mathrm{o}}=\mathrm{D}_{\mathrm{f}} \gamma_{\mathrm{b}}$. serta nilai $\gamma$ pada suku persamaan ketiga menjadi $\gamma_{\mathrm{b}}$. Berikut gambar pengaruh muka air tanah kondisi 1.

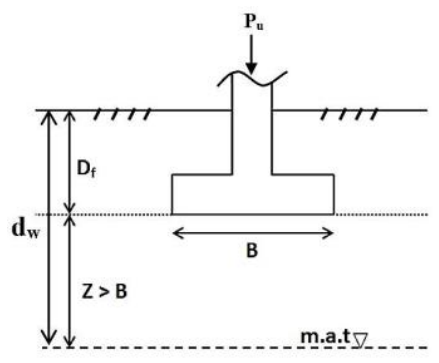

Gambar 4. Pengaruh Muka Air Tanah Kondisi 1 (Sumber : Teknik Pondasi I, Hardiyatmo 1996).

2. Kondisi 2: $\mathrm{p}_{\mathrm{o}}=\left[\gamma^{\prime}\left(\mathrm{Df}-\mathrm{d}_{\mathrm{w}}\right)+\gamma_{\mathrm{b}} \mathrm{d}_{\mathrm{w}}\right]$.

Nilai $\gamma$ pada suku persamaan ketiga menjadi $\gamma^{\prime}$ dimana $\gamma^{\prime}=\gamma_{\mathrm{sat}}-\gamma_{\mathrm{w}}$

Berikut gambar pengaruh muka air tanah kondisi 2.

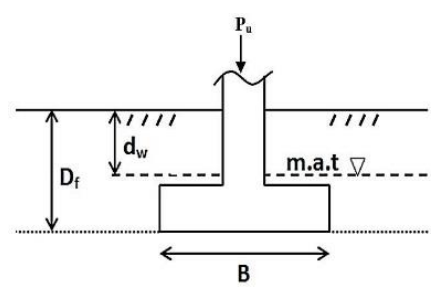

Gambar 5. Pengaruh Muka Air Tanah Kondisi 1 (Sumber : Teknik Pondasi I, Hardiyatmo 1996).

3. Kondisi 3: $p_{o}=D_{f} \gamma$ dan nilai $\gamma$ pada suku persamaan ketiga menjadi $\gamma_{\mathrm{r}}$ dimana, $\gamma_{\mathrm{r}}=\gamma^{\prime}+\left({ }^{\mathrm{z}} / \mathrm{B}\right)\left(\gamma_{\mathrm{b}^{-}} \gamma^{\prime}\right)$. Berikut gambar pengaruh muka air tanah kondisi 3. 


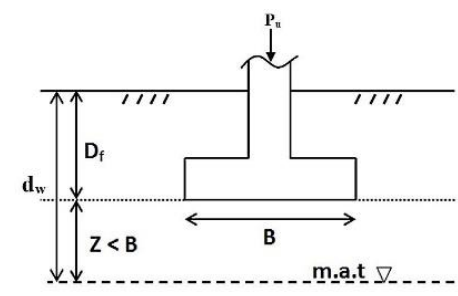

Gambar 6. Pengaruh Muka Air Tanah Kondisi 1 (Sumber : Teknik Pondasi I, Hardiyatmo 1996).

\subsection{MIT App Inventor}

Terdapat beberapa kelebihan yang dimiliki MIT App Inventor ini antara lain:

1. Bahasa pemrograman berbasis blok visual yang disusun seperti puzzle.

2. Pembuatan aplikasi hanya dengan cara mengakses website appinventor.mit.edu.

3. Hasil aplikasi dapat diunduh dan dijalankan pada telepon pintar Android.

Kekurangan aplikasi antara lain:

\section{Database internal sehingga penyimpanan hanya dalam aplikasi saja.}

Pemodelan interface atau tampilan terlalu kaku sehingga sedikit rumit dalam mendesain tampilan.

\section{METODE PEMODELAN}

\subsection{Bagan Air Studi}

Berikut gambar bagan alir studi penelitian ini.

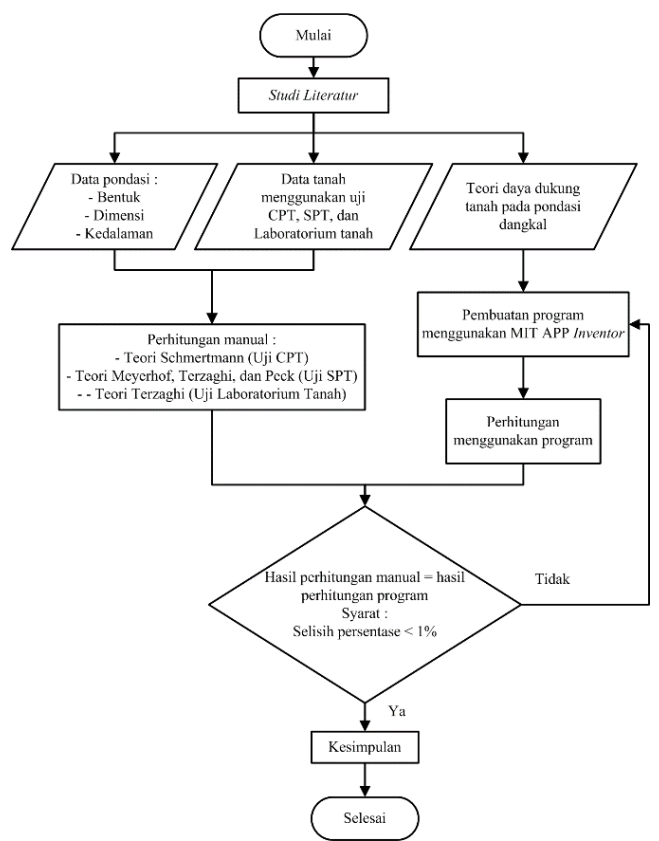

Gambar 7. Bagan Alir Studi.

\subsection{Tahapan Proses Pembuatan Program \\ Diagram alir tahapan program yaitu:}

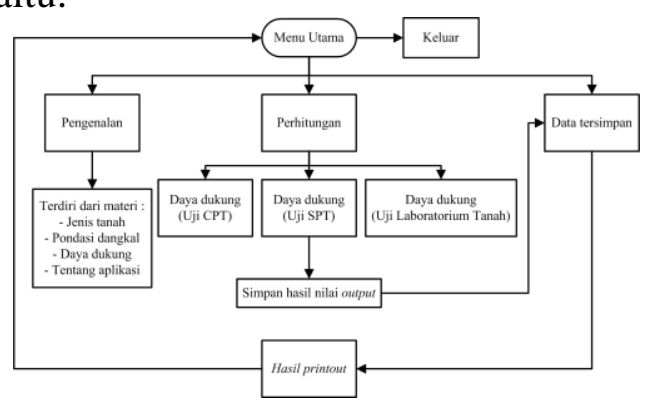

Gambar 8. Diagram Alir Program Utama.

\section{PEMODELAN DAN PEMBAHASAN 4.1 Hasil Pemodelan dan Perbandingan Pembuatan program pemodelan daya dukung pondasi dangkal dimulai dari data input, proses data dan output data. Terdapat 3 studi kasus yang telah dipilih, yaitu proyek Ruko Sriwijaya, Wisma Mugasari, dan Gedung Kantor Demak.}




\subsubsection{Perhitungan Menggunakan Data Uji CPT}

1. Data Proyek

Data proyek yang digunakan antara lain:

Identitas proyek $=$ Ruko Jalan

Kode titik uji $=3$

Sriwijaya Semarang

Beban bangunan $=85125 \mathrm{~kg}=85,125$

ton

Jenis pondasi $=$ Setempat bujur sangkar

Kedalaman pondasi $\left(D_{f}\right)=2 \mathrm{~m}$

Lebar pondasi $(\mathrm{B})=1,2 \mathrm{~m}$

Nilai keamanan $(\mathrm{Fk})=3$

Tampilan posisi pondasi proyek ruko ini dapat dilihat pada gambar berikut ini.

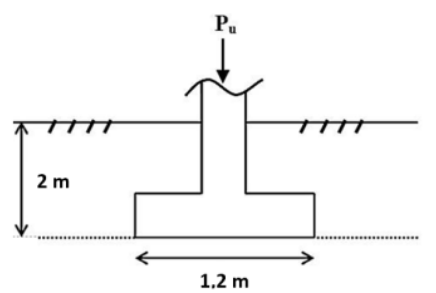

Gambar 9. Tampilan Posisi Pondasi Proyek Ruko Sriwijaya

Tabel 3. Data Hasil CPT Proyek Ruko Sriwijaya

\begin{tabular}{ccc}
\hline $\begin{array}{c}\text { Kedalaman } \\
(\mathbf{m})\end{array}$ & $\begin{array}{c}\text { Tahanan } \\
\text { Konus, } \mathbf{q} \\
\left(\mathbf{k g} / \mathbf{c m}^{2}\right)\end{array}$ & $\begin{array}{c}\text { Rasio } \\
\text { Gesekan, } \mathbf{f} \text { } \\
(\mathbf{\%})\end{array}$ \\
\hline 2,0 & 40,00 & 2,75 \\
\hline 2,2 & 35,00 & 2,86 \\
\hline 2,4 & 35,00 & 2,86 \\
\hline 2,6 & 35,00 & 3,14 \\
\hline 2,8 & 70,00 & 2,86 \\
\hline 3,0 & 90,00 & 2,22 \\
\hline 3,2 & 150,00 & 1,67 \\
\hline
\end{tabular}

2. Perhitungan Program

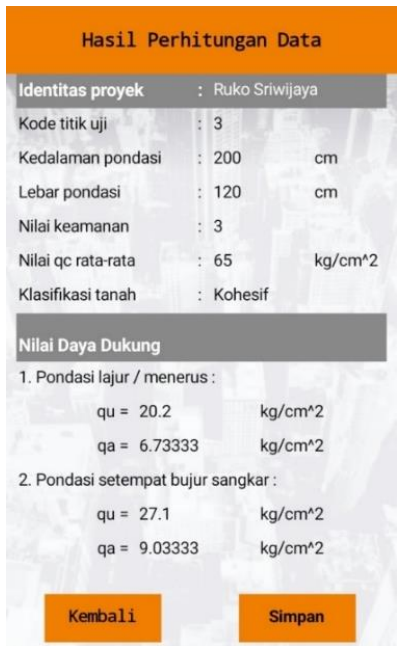

Gambar 10. Hasil Output Program Data CPT

3. Perbandingan perhitungan program dengan manual

Tabel 4. Perbandingan Nilai $\mathrm{q}_{\mathrm{a}}$ Pada Pondasi Menerus

\begin{tabular}{ccccc}
\hline $\begin{array}{c}\text { Not } \\
\text { asi }\end{array}$ & $\begin{array}{c}\text { Satu } \\
\text { an }\end{array}$ & $\begin{array}{c}\text { Man } \\
\text { ual }\end{array}$ & $\begin{array}{c}\text { Progr } \\
\text { am }\end{array}$ & $\begin{array}{c}\text { Persent } \\
\text { ase } \\
(\%)\end{array}$ \\
\hline $\mathrm{q}_{\mathrm{a}}$ & $\begin{array}{c}\mathrm{kg} / \mathrm{c} \\
\mathrm{m}^{2}\end{array}$ & 6,73 & $\begin{array}{c}6,733 \\
3\end{array}$ & $\begin{array}{c}0,0490 \\
3\end{array}$ \\
\hline
\end{tabular}

Tabel 5. Perbandingan Nilai $\mathrm{q}_{\mathrm{a}}$ Pada Pondasi Setempat Bujur Sangkar

\begin{tabular}{ccccc}
\hline $\begin{array}{c}\text { Not } \\
\text { asi }\end{array}$ & $\begin{array}{c}\text { Satu } \\
\text { an }\end{array}$ & $\begin{array}{c}\text { Man } \\
\text { ual }\end{array}$ & $\begin{array}{c}\text { Progr } \\
\text { am }\end{array}$ & $\begin{array}{c}\text { Persent } \\
\text { ase } \\
(\%)\end{array}$ \\
\hline $\mathrm{q}_{\mathrm{a}}$ & $\begin{array}{c}\mathrm{kg} / \mathrm{c} \\
\mathrm{m}^{2}\end{array}$ & 9,03 & $\begin{array}{c}9,033 \\
3\end{array}$ & 0,0365 \\
\hline & Dari & hasil & perbandingan hasil
\end{tabular}
perhitungan tersebut terdapat selisih angka antara perhitungan manual dengan perhitungan menggunakan program sebesar $0,04903 \%$. 


\subsubsection{Perhitungan Menggunakan Data Uji SPT}

1. Data Proyek

Data proyek yang digunakan antara lain:

Identitas proyek $=$ Wisma Mugasari Semarang

Kode titik uji $=$ BH1

Beban bangunan $=160102,7 \mathrm{~kg}=$ 160,1027 ton

Jenis pondasi $=$ Setempat bujur sangkar Kedalaman pondasi $\left(\mathrm{D}_{\mathrm{f}}\right)=2 \mathrm{~m}$

Lebar pondasi $(\mathrm{B})=2,75 \mathrm{~m}$

Nilai keamanan $(\mathrm{Fk})=3$

Tampilan posisi pondasi proyek wisma ini dapat dilihat pada gambar berikut ini.

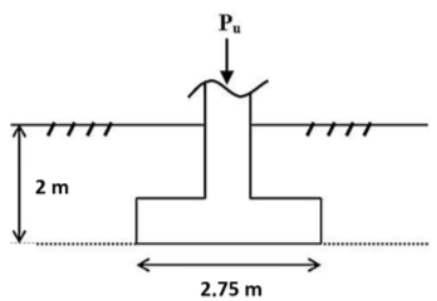

Gambar 11. Tampilan Posisi Pondasi Proyek Wisma Mugasari

Tabel 6. Data Hasil SPT Proyek Wisma Mugasari

\begin{tabular}{cc}
\hline $\begin{array}{c}\text { Kedalaman } \\
(\mathbf{m})\end{array}$ & $\begin{array}{c}\mathbf{N}_{\text {SPT }} \\
(\text { blow })\end{array}$ \\
\hline 0 & 0 \\
\hline 2 & 11 \\
\hline 4 & 15 \\
\hline 6 & 31 \\
\hline
\end{tabular}

\section{Perhitungan Program}

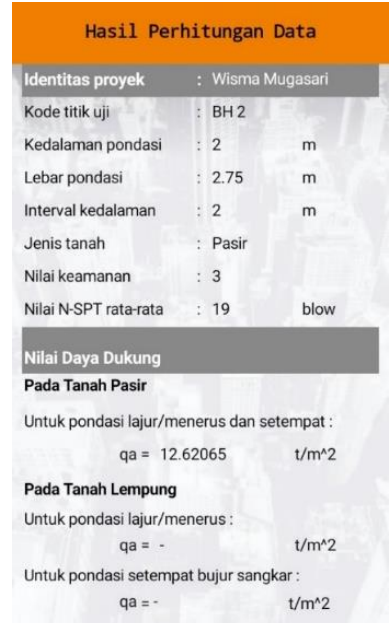

Gambar 12. Hasil Output Program Data SPT

3. Perbandingan perhitungan program dengan manual

Tabel 7. Perbandingan Nilai $\mathrm{q}_{\mathrm{a}}$

\begin{tabular}{ccccc}
\hline $\begin{array}{c}\text { Nota } \\
\text { si }\end{array}$ & $\begin{array}{c}\text { Satu } \\
\text { an }\end{array}$ & $\begin{array}{c}\text { Manu } \\
\text { al }\end{array}$ & $\begin{array}{c}\text { Progr } \\
\text { am }\end{array}$ & $\begin{array}{c}\text { Persent } \\
\text { ase }(\%)\end{array}$ \\
\hline \multirow{2}{*}{$\mathrm{q}_{\mathrm{a}}$} & $\mathrm{t} / \mathrm{m}^{2}$ & $\begin{array}{c}12,62 \\
1\end{array}$ & $\begin{array}{c}12,620 \\
65\end{array}$ & 0,003 \\
\hline & Dari & hasil & perbandingan
\end{tabular}

perhitungan tersebut terdapat selisih angka antara perhitungan manual dengan perhitungan program sebesar $0,003 \%$.

\subsubsection{Perhitungan Menggunakan Data Uji Laboratorium Sampel Tanah}

1. Data Proyek

Data proyek yang digunakan antara lain:

Identitas proyek $=$ Gedung Kantor di Kabupaten Demak

Kode sampel uji $=$ B1-2

Beban bangunan $=64400 \mathrm{~kg}=64,4$ ton Jenis pondasi $=$ Setempat bujur sangkar Kedalaman pondasi $\left(\mathrm{D}_{\mathrm{f}}\right)=2 \mathrm{~m}$ Lebar pondasi $(\mathrm{B})=2,2 \mathrm{~m}$ Nilai keamanan $(\mathrm{Fk})=3$ 
Data Hasil Uji Laboratorium Sampel Tanah

Berat volume tanah basah, $\gamma_{\mathrm{b}}=1,869$ $\mathrm{t} / \mathrm{m}^{3}$

Sudut geser tanah, $\phi=30^{\circ}$

Kohesi, $\mathrm{c}=0,08 \mathrm{~kg} / \mathrm{cm}^{2}=0,8 \mathrm{t} / \mathrm{m}^{2}$

Tampilan posisi pondasi proyek ini dapat dilihat pada gambar berikut ini.

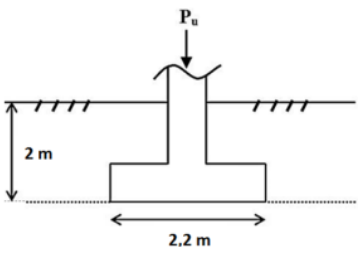

Gambar 13. Tampilan Posisi Pondasi Proyek Gedung Kantor Demak

2. Perhitungan Program

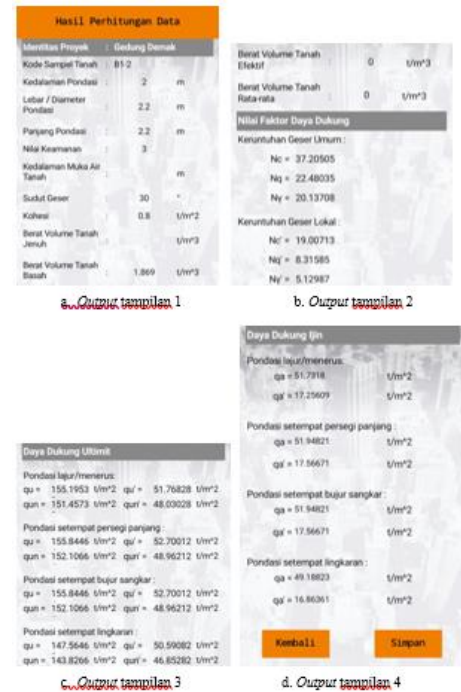

Gambar 14. Hasil Output Program Data Uji Laboratorium Tanah

3. Perbandingan perhitungan program dengan manual

Tabel 8. Perbandingan Nilai $\mathrm{q}_{\mathrm{a}}$ Pada Keruntuhan Geser Umum

\begin{tabular}{|c|c|c|c|}
\hline $\begin{array}{c}\text { Jenis } \\
\text { Pondasi }\end{array}$ & $\begin{array}{c}\text { Manu } \\
\text { al }\end{array}$ & $\begin{array}{c}\text { Progra } \\
\text { m }\end{array}$ & $\begin{array}{c}\text { Persentas } \\
\text { e }(\%)\end{array}$ \\
\hline $\begin{array}{l}\text { Memanja } \\
\text { ng }\end{array}$ & 51,731 & 51,732 & 0,0014 \\
\hline
\end{tabular}

\begin{tabular}{llll}
\hline $\begin{array}{l}\text { Persegi } \\
\text { Panjang }\end{array}$ & 51,948 & 51,948 & 0,0005 \\
\hline $\begin{array}{l}\text { Bujur } \\
\text { Sangkar }\end{array}$ & 51,948 & 51,948 & 0,0005 \\
\hline $\begin{array}{l}\text { Lingkara } \\
\mathrm{n}\end{array}$ & 49,188 & 49,188 & 0,0005 \\
\hline
\end{tabular}

Tabel 9. Perbandingan Nilai $\mathrm{q}_{\mathrm{a}}$ Pada Keruntuhan Geser Lokal

\begin{tabular}{|c|c|c|c|}
\hline $\begin{array}{c}\text { Jenis } \\
\text { Pondasi }\end{array}$ & $\begin{array}{c}\text { Manu } \\
\text { al }\end{array}$ & $\begin{array}{c}\text { Progra } \\
\text { m }\end{array}$ & $\begin{array}{c}\text { Persenta } \\
\text { se }(\%)\end{array}$ \\
\hline $\begin{array}{l}\text { Meman- } \\
\text { jang }\end{array}$ & 17,256 & 17,256 & 0,0020 \\
\hline $\begin{array}{l}\text { Persegi } \\
\text { Panjang }\end{array}$ & 17,567 & 17,567 & 0,0004 \\
\hline $\begin{array}{l}\text { Bujur } \\
\text { Sangkar }\end{array}$ & 17,567 & 17,567 & 0,0004 \\
\hline $\begin{array}{l}\text { Lingkar- } \\
\text { an }\end{array}$ & 16,864 & 16,864 & 0,0011 \\
\hline $\begin{array}{l}\text { Da } \\
\text { perhitunga } \\
\text { antara } p \\
\text { perhitunga } \\
\text { sebesar } 0,0\end{array}$ & $\begin{array}{l}\text { ri hasil } \\
\text { n tersebs } \\
\text { erhitung } \\
\text { n me } \\
02 \% \text {. }\end{array}$ & $\begin{array}{l}\text { perband } \\
\text { terdapat } \\
\text { ggunakan }\end{array}$ & $\begin{array}{l}\text { gan hasi } \\
\text { elisih angk } \\
\text { progran }\end{array}$ \\
\hline
\end{tabular}

\section{KESIMPULAN DAN SARAN}

\subsection{Kesimpulan} yaitu:

Kesimpulan dari penelitian ini

a. Program daya dukung tanah pondasi dangkal berbasis MIT App Inventor ini diketahui pada masing-masing uji kurang dari $1 \%$, maka program dapat digunakan dan dikembangkan lebih lanjut.

b. Perhitungan daya dukung tanah pondasi dangkal menggunakan program lebih efektif dan efisien dalam segi waktu 
dibandingkan dengan perhitungan secara manual.

\subsection{Saran} yaitu:

Saran yang dapat disampaikan

a. Diharapkan perhitungan program dapat dilanjutan hingga penulangan pondasi.

b. Mengembangkan perhitungan program menggunakan metode lain.

c. Output program dapat ditambah jenis pondasi dangkal lain yaitu pondasi rakit, pondasi gabungan, dan pondasi cangkang (shell foundation).

\section{DAFTAR PUSTAKA}

Bowles, Joseph. 1992. Analisis dan Desain Pondasi Jilid 1. Jakarta : Erlangga.

Das, Braja M. 1995. Mekanika Tanah 1 Jilid I. Jakarta : Erlangga.

Das, Braja M. 1995. Mekanika Tanah 2 Jilid II. Jakarta : Erlangga.

Das, Braja M. 2007. Principles of Foundation Engineering 7th Edition. Canada : Cengage Learing.

Hardiyatmo, Hary Christady. 1994. Mekanika Tanah I1. Jakarta : PT. Gramedia Pustaka Utama

Hardiyatmo, Hary Christady. 1996. Teknik Pondasi 1. Jakarta : PT. Gramedia Pustaka Utama.

Haryanto. 2005. Aplikasi Struktur Shell Pada Sydney Opera House. Semarang : Universitas Diponegoro.

Herbowo, Setya dan Razaqy A. Y.. 2015. Pemodelan Daya Dukung Pondasi Dangkal Dengan Bahasa Visual Basic 6. Tugas Akhir Program Studi Teknik
Sipil, Universitas Katolik Soegijapranata Semarang.

McCormac, Jack C. 2004. Desain Beton Bertulang Jilid 2. Jakarta : Penerbit Erlangga

Muntaha, Ahmad. 2007. Aplikasi Perencanaan Pondasi Dangkal Dengan Program Borland Delphi 6.0. Tugas Akhir Program Studi Teknik Sipil, Universitas Jember.

PPIUG 1983. 1983. Peraturan Pembebanan Indonesia Untuk Gedung. Bandung : Direktorat Penyeldikan Masalah Bangunan.

SNI 2827:2008. 2008. Cara Uji Penetrasi Lapangan Dengan Alat Sondir. Jakarta : Badan Standardisasi Nasional.

SNI 4153:2008. 2008. Cara Uji Penetrasi Lapangan Dengan SPT. Jakarta : Badan Standardisasi Nasional. 